\title{
Biosorption of Lead (II) from aqueous solution and Industrial Effluent by using leaves of Araucaria cookii: Application of Response Surface Methodology
}

\author{
Deepa C. N, Suresha. S* \\ (Department of Environmental Science, Yuvaraj's College, University of Mysore, Mysore \\ 570005, Karnataka, India)
}

\begin{abstract}
The aim of the present study involves the biosorption of Pb (II) by using the leaves Araucaria cookii from aqueous solution and industrial effluent. The batch studies were performed to evaluate the different parameters like $\mathrm{pH}$, contact time, metal ion concentration, adsorbent mass and size variation. Characterization of biosorbent was carried out by Fourier Transform Infrared (FTIR) and Scanning Electron Micrograph (SEM). Experimental results shows that at $\mathrm{pH} 5$ the biosorption efficiency reached a maximum removal of $98.52 \%$ with a contact time of $60 \mathrm{~min}$ and an initial ion concentration $200 \mathrm{mg} / \mathrm{L}$. Kinetic models are described and fitted good with Pseudo- second order reaction. Langmuir and Freundlich isotherms were also applied and evaluated. The Central Composite experimental Design (CCD) in Response Surface Methodology was used to design the experiment and the optimum conditions. The result showed that the model and experimental data was favourable in the removal of Lead (II) in the industrial waste water and can be used as low cost biosorbent.
\end{abstract}

Keywords: Araucaria cookii, biosorption, Lead (II), Langmuir \& Freundlich isotherms, RSM

\section{Introduction}

Natural waters have been found to be contaminated with rapid industrialization which leads to an increased disposal of heavy metals in the environment. Heavy metals are among the conservative pollutants that are not subject to bacterial attack or other break down or degradation process and are a permanent addition to the marine environment $[1,2]$. Heavy metal ions such as cobalt, copper, nickel, chromium, lead, and zinc are detected in the waste streams from mining operations, tanneries, electronics, electroplating, batteries and petrochemical industries as well as textile mill products. Major lead pollution is through automobiles and battery manufacturers [3].

Lead is considered as one of the top sixteen toxic pollutants because of its carcinogenic characteristics for humans [4]. Lead is used as electrodes in the process of electrolysis [5]. The permissible limit of lead (II) in drinking water is $0.05 \mathrm{mg} / \mathrm{l}$ [6]. The maximum discharge limits for $\mathrm{Pb}$ (II) in waste water is $0.05 \mathrm{mg} / 1$ [7] and sewage sludge applied to agriculture land is $420 \mathrm{mg} / 1$ [8] as set by the Environment protection Agency.

Toxic levels of lead in human beings have been associated with encephalopathy seizures and mental retardation [9]. Lead poisoning causes severe damage to the Kidneys, nervous system, reproductive system, liver and brain [10]. Lead is known to inhibit the activity of three critical enzymes (5- aminolaevulinate dehydrase (ALA-D), coproporphyrinogen oxidase (COPRO-O) and ferrochelatase (FERRO-C) critical in haem synthesis, causing abnormal concentrations of haem precursors in blood and urine [11]. Contamination of water through anthropogenic practices is the primary cause of lead poisoning in fish [12].

The several methods which were used for the treatment of waste water include Precipitation, adsorption with activated carbon, ion exchange, membrane processes, oxidation and reduction [13]. But, technical and economical factors limit sometimes the feasibility of such process $[14,15]$.

The promising method for heavy metal removal from waste water is biosorption. Biosorption is an economically feasible means for the removal and/or recovery of heavy binding abilities of various biological materials. Recently, there has been an intensive study on the use of seeds, pods, and bark of plants which is called as biomass in removing heavy metals from waste water. In addition, studies have been carried out to ascertain the optimum conditions necessary for efficient removal of these metals from polluted sites [11, 16].

Response surface methodology (RSM) is a collection of mathematical and statistical techniques useful for analyzing the effects of several independent variables on the response [17]. RSM generates an experimental design for model preparation. An experimental design is a specific set of experiments defined by a matrix composed of the different level combinations of the variables studied [18].

In this study, the leaves of Araucaria cookii which belong to the family Araucariaceae are used as a low cost biosorbent for the removal of $\mathrm{Pb}$ (II). The factors studied include $\mathrm{pH}$, contact time, dosage, size variation and metal ion concentration. Experimental data is obtained by using Langmuir and Freundlich isotherms. Kinetic studies of Pseudo first order and Pseudo second order reactions have been carried out. 


\subsection{Biomass Preparation}

\section{Materials and Methods}

The leaves were collected from the premises of Manasa gangotri, University of Mysore, Mysore, Karnataka, India. The leaves were sun dried for one month and ground approximately to different particle sizes from $100 \mu \mathrm{m}-400 \mu \mathrm{m}$ in size. The biosorbent was washed with double distilled water several times to remove the floatable biomass and sun dried for 5 days. The samples were kept in an air tight plastic jar until the usage for the experiment.

\subsection{Preparation of Adsorbate}

Metal ion solution of $\mathrm{Pb}$ (II) was prepared from Lead nitrate (Merck- A.R. grade). About $1.598 \mathrm{~g}$ of lead nitrate was weighed and a standard stock solution of concentration $1000 \mathrm{mg} / \mathrm{l}^{-}$was prepared in double distilled water and further working solutions of lower concentrations were prepared as and when required. The $\mathrm{pH}$ of the solution was adjusted using $0.01 \mathrm{M} \mathrm{HCl}$ and $0.01 \mathrm{M} \mathrm{NaOH}$. The final concentration of metal ions were analysed by AAS.

\subsection{Industrial effluent:}

The effluent was collected from a Paper industry in Nanjangud Taluk, Mysore, Karnataka, India. The effluent was collected in a clean plastic container and stored in the refrigerator until further experiments and its Physico - Chemical characteristics of effluent was analysed according to standard methods described by the American Public Health Association (APHA; APHA 1998) [19] and the results are presented in Table 1.

Table -1 Physico-chemical Characteristics of Paper Industry Effluent

\begin{tabular}{cl}
\hline Parameters & Contents (mg/l) \\
\hline $\mathrm{pH}$ & 3.0 \\
\hline Conductivity $(\mu \mathrm{s} / \mathrm{cm})$ & 1980 \\
\hline Total Dissolved Solids & 1531 \\
\hline COD $(\mathrm{mg} / \mathrm{L})$ & 520 \\
\hline Calcium $(\mathrm{mg} / \mathrm{L})$ & 110.5 \\
\hline Magnesium $(\mathrm{mg} / \mathrm{L})$ & 51.6 \\
\hline Chloride $(\mathrm{mg} / \mathrm{L})$ & 215.2 \\
\hline Sulphate $(\mathrm{mg} / \mathrm{L})$ & 56.0 \\
\hline Sodium $(\mathrm{mg} / \mathrm{L})$ & 80.5 \\
\hline Potassium $(\mathrm{mg} / \mathrm{L})$ & 5.0 \\
\hline Lead $(\mathrm{II})$ & 6.0 \\
\hline Zinc $(\mathrm{II})$ & 22 \\
\hline Nickel $(\mathrm{II})$ & 5
\end{tabular}

\subsection{Characterization of Biosorbent:}

A Fourier Transform Infrared (FTIR) spectrum of unloaded and metal bound $A$. cookii samples were recorded by using standard $\mathrm{KBr}$ pellet method to obtain the spectrum using Jasco FT / IR- 4100 in wave number range of 400-4000 $\mathrm{cm}^{-1}$. The scanning electron micrograph was used to reveal the surface texture and morphology of the biosorbent by using ZEISS , EVO/LS 15-15-41, smart SEM version 5.05.

\subsection{Optimization procedure: Central Composite Design (CCD)}

Response surface methodology (RSM) procedure [20, 21] was used for optimising the process variables. The three main steps involved in this process are experimental design, modelling and optimization. RSM model shows relatively few combinations of variables for determination of complex response function [22]. In the present study, the Central Composite Design model has been used for the optimization of lead Biosorption. The five variables of lead ions were $\mathrm{pH}$, contact time, metal ion concentration, biomass and size variation. The independent process variables of RSM in the quantitative form are represented as follows:

$$
Y=f\left(A_{1}, A_{2}, A_{3} \ldots \ldots\right.
$$

where, $Y$ is the amount of metal adsorbed $\left(\mathrm{mg} \mathrm{L}^{-1}\right), \mathrm{f}$ is the response function and $\mathrm{A}_{1}, \mathrm{~A}_{2}, \mathrm{~A}_{3} \ldots$ independent variables

In the linear manner, if the response varies, the linear function can be given by the following formula:

$$
\mathrm{Y}=\mathrm{b}_{0}+\mathrm{b}_{1} \mathrm{~A}_{1}+\mathrm{b}_{2} \mathrm{~A}_{2}+\text {---------------- }+\mathrm{b}_{2} \mathrm{~A}_{\mathrm{n}}
$$

Where $b_{0}$, offset term; $A_{i}$ first order main effect: $A_{i i}$ second order main effect and $A_{i j}$ interaction effect. 
Biosorption of Lead in Aqueous solution and Industrial Effluent by using leaves of Araucaria .....

Table. 2 Different parameters chosen for the biosorption as independent variables.

\begin{tabular}{ccccc} 
Factor & Name & Units & Minimum & Maximum \\
\hline $\mathrm{A}$ & $\mathrm{pH}$ & & 2 & 7 \\
\hline $\mathrm{B}$ & Biomass & $\mathrm{g}$ & 0.5 & 4 \\
\hline $\mathrm{C}$ & concentration & $\mathrm{mg} / \mathrm{g}$ & 50 & 250 \\
\hline $\mathrm{D}$ & Time & $\mathrm{min}$ & 5 & 90 \\
\hline $\mathrm{E}$ & Size variation & Micron & 100 & 400 \\
\hline
\end{tabular}

If there is a curvature in the system, the higher order polynomial quadratic model which is used can be stated as:

$$
\mathrm{Y}=\mathrm{b}_{0}+\sum \mathrm{b}_{\mathrm{i}} \mathrm{A}_{\mathrm{i}}+\sum \mathrm{b}_{\mathrm{ii}} \mathrm{A}_{\mathrm{i}}^{2}+\sum \mathrm{b}_{\mathrm{ij}} \mathrm{A}_{\mathrm{i}} \mathrm{A}_{\mathrm{j}}
$$

There are five parameters in this study mainly $\mathrm{pH}$, contact time, metal ion concentration, adsorbent dose, and particle size variation and these parameters were studied using the CCD model with two levels minimum and maximum. The model consists of $\mathrm{pH}$ (2-10), contact time (5- $90 \mathrm{~min})$, metal ion concentration (50 - $250 \mathrm{ppm})$, adsorbent dose $(0.5-4 \mathrm{~g})$ and particle size from $(100-400 \mu)$ and the independent variables of these parameters are shown in Table 2 . The correlation co efficient $\mathrm{R}^{2}$ value was also calculated to analyse the variance whether this model is good and appropriate.

\subsection{Batch Experiments}

Metal analysis was carried out in the batch method. The biosorption studies were carried out in the experimental conditions for different $\mathrm{pH} \mathrm{1-7,} \mathrm{contact} \mathrm{time} \mathrm{5-90} \mathrm{min,} \mathrm{metal} \mathrm{ion} \mathrm{concentration} 50-250 \mathrm{mgL}^{-1}$, adsorbent dose 0.5- $4.0 \mathrm{~g}$ and size variation 100- $400 \mu$. Each batch experiment was carried out by taking $2 \mathrm{~g}$ powder of $A$. cookii leaves with $20 \mathrm{ml}$ of $1000 \mathrm{mgL}^{-1}$ in an Erlenmeyer flask. A stirring speed of $200 \mathrm{RPM}$ was kept constant in the rotary shaker with the appropriate time intervals from 5- $90 \mathrm{~min}$. The stirred solution is filtered and the decanted solution was analysed using AAS. The mean value was calculated by repeating the experiment.

The adsorbed metal is based on the soluble metal concentration before and after the batch experiment. The amount of percent removal can be calculated as:

$$
\mathrm{q}_{\mathrm{e}}(\mathrm{mg} / \mathrm{g})=\mathrm{V}\left(\mathrm{C}_{0}-\mathrm{C}_{\mathrm{e}}\right) / \mathrm{m}
$$

Where $C_{0}$ is the initial concentration $(\mathrm{mg} / \mathrm{l})$ and $\mathrm{C}_{\mathrm{e}}$ is the equilibrium metal concentration $(\mathrm{mg} / \mathrm{l}), \mathrm{V}$ is the volume of metal solution $(\mathrm{L})$ and $\mathrm{m}$ is the mass of the biosorbent.

\subsection{FTIR analysis}

\section{Results and discussion}

The FT- IR spectroscopy method was used to obtain information about the nature of the functional groups responsible for the biosorption of metal ions on the binding sites of the biosorbents [23, 24, 25]

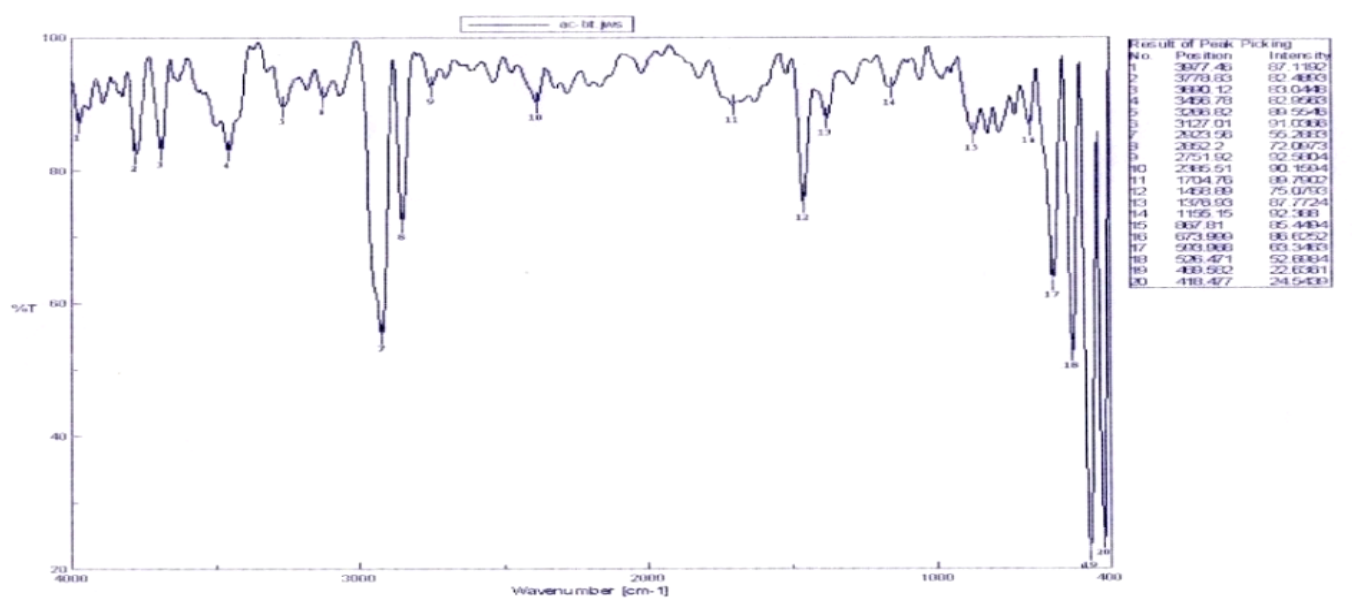

Fig. 1 FTIR spectra of unloaded A. cookii 


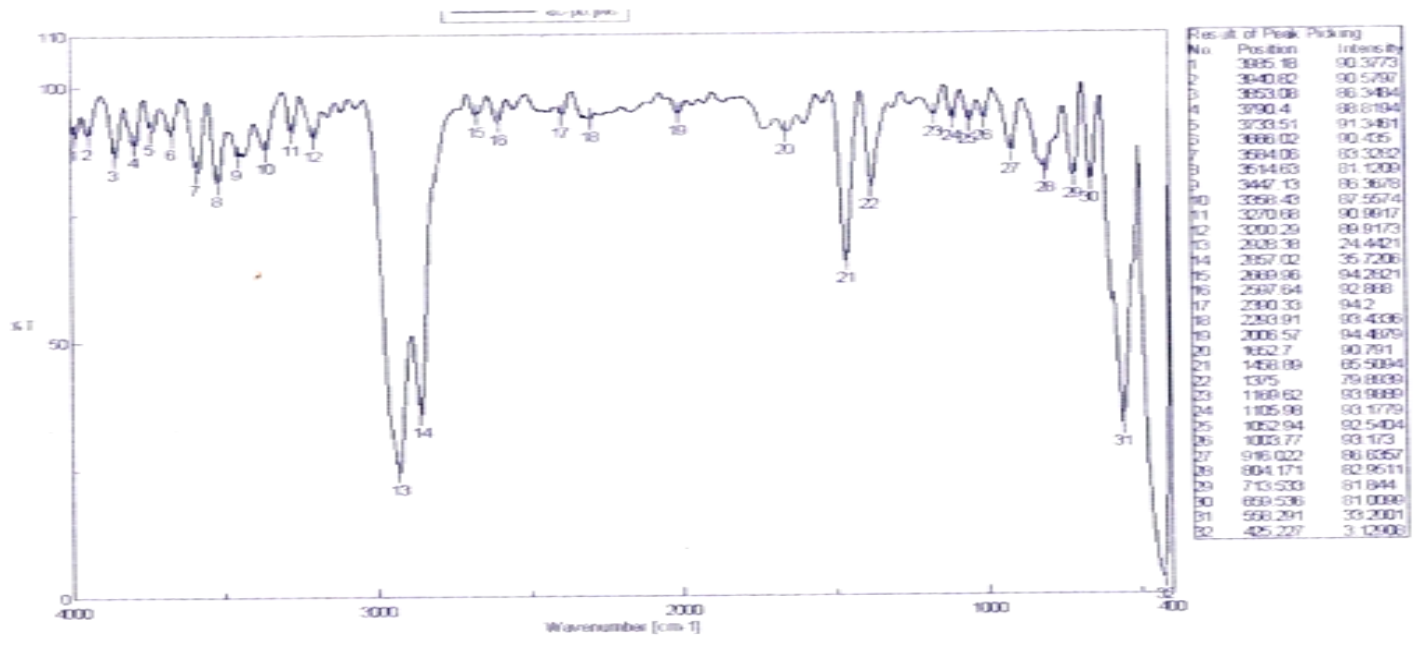

Fig. 2 FTIR spectra of $\mathrm{Pb}$ (II) loaded A.cookii

The powder of $A$.cookii leaves were sieved to a particle size ranging between 100 to $400 \mu \mathrm{m}$ sizes. 100 $\mu \mathrm{m}$ particle size were used for adsorption studies and were characterised by FTIR studies of before and after adsorption shown in Fig-1 and Fig-2 respectively. The peak at 3690 and $3456 \mathrm{~cm}^{-1}$ is the indicator of O-H (free) and $-\mathrm{NH}$ groups. The stretching of $-\mathrm{OH}$ groups bound to methyl group radicals presented in figure between 2983 and $2852 \mathrm{~cm}^{-1}$. The peaks located at 2923 and $2751 \mathrm{~cm}^{-1}$ are the characteristics of carbonyl group stretching from aldehyde and ketones. The appearance of $-\mathrm{OH}$ group and $\mathrm{C}-\mathrm{O}$ group confirms the presence of carboxylic group in the biosorbent. The peak 1458 and $1376 \mathrm{~cm}^{-1}$ are characterising the presence of Nitroso $\mathrm{N}=\mathrm{O}$ stretching and $\mathrm{S}=\mathrm{O}$ sulfonyl groups associated with stretching aromatic rings. The peaks observed at 1155,867 , and 673 $\mathrm{cm}^{-1}$ are due to $\mathrm{C}=\mathrm{S}$ (Thiocarbonyl) and S-OR esters stretching. The $-\mathrm{OH}$, - NH, carbonyl, carboxylic groups are important sorption sites [26]. The FTIR spectrum of the A.cookii after biosorption of $\mathrm{Pb}$ (II) is shown in the Fig 2 reveals that the involvement of Hydroxyl and carboxyl groups in the biosorption.

\subsection{SEM analysis}

(A)

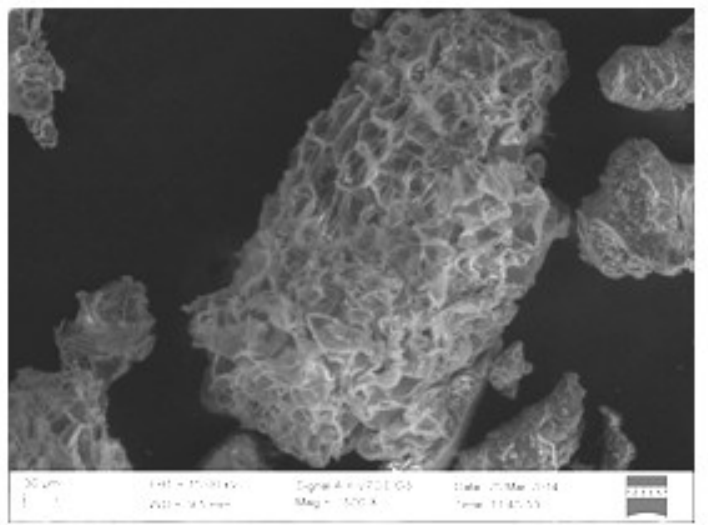

(B)

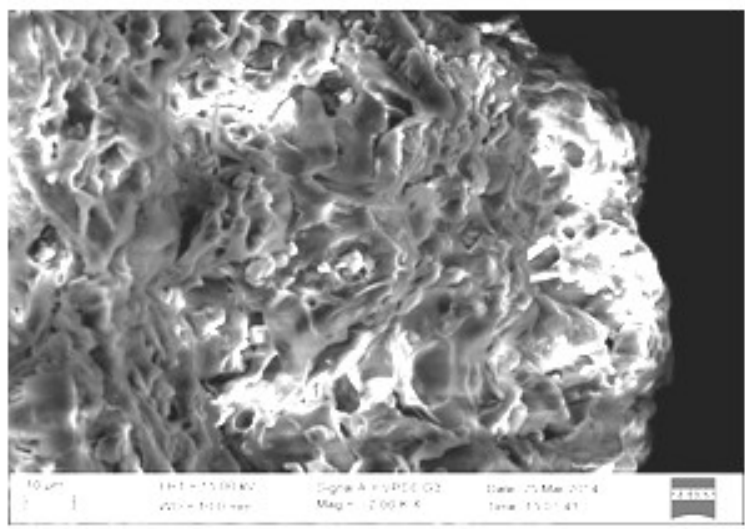

Figure 3 (a) shows the SEM pictures of raw A.cookii and Figure 3(b) shows the SEM pictures of loaded A.cookii

Figure 3 (a) and (b) shows the SEM image of A.cookii which were used in the experiments. SEM clearly reveals the surface texture and morphology of the biosorbent. An amorphous structure with no definite surface can be seen in native biosorbents (Fig 3a). Fig 3(b) shows progressive changes in the surface particles with native biosorbent which depicts that $\mathrm{Pb}$ (II) ion have deposited as aggregates in the biosorbent.

\subsection{Effect of $\mathrm{pH}$}

The $\mathrm{pH}$ of the solution is one of the most important parameter from the aqueous solution. $2 \mathrm{~g}$ of biosorbent was taken in an Erlenmeyer flask with the $\mathrm{pH}$ range of $1-7$ with $20 \mathrm{ml}$ of $1000 \mathrm{mgL}^{-1}$ of $\mathrm{Pb}$ (II) 
solution. The solution is stirred for half an hour at a speed of $200 \mathrm{rpm}$ in a mechanical shaker, the resultant solution is filtered, decanted and the $\mathrm{Pb}$ (II) solution is measured by AAS.

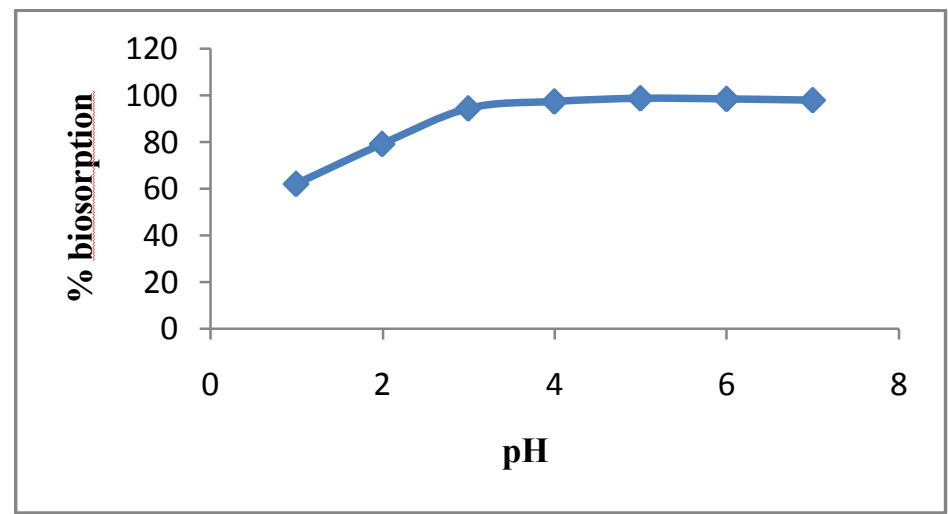

Figure.3 Effect of $\mathrm{pH}$ on adsorption of $\mathrm{Pb}$ (II) by A.cookii

The effect of biosorption of $\mathrm{pH}$ on $\mathrm{Pb}$ (II) is shown in Fig 3. The result shows that the percentage adsorption of $\mathrm{Pb}$ (II) increases from 62.07- 98.52\% with increase in $\mathrm{pH}$ from 1.0 to 5.0, afterwards the rate of adsorption is stable. This may be due to the hydrogen ions which are strong competing ions and also influence the chemical speciation of functional groups on the surface of the adsorbents. Depending upon the $\mathrm{pH}$, lead can be found in various forms, at $\mathrm{pH}<5$ approximately $79 \%$ of $\mathrm{Pb}^{2+}$ and $21 \%$ of $\mathrm{PbNO}_{3}$ will be at equilibrium and when the solution of the $\mathrm{pH}$ increases beyond 5, it begins to precipitate forming $\left[\mathrm{Pb}(\mathrm{OH})_{2}\right]$ which is insoluble. So when the solution is in the solid lead hydroxide which is to be able to bind the negatively charged groups of the biomass decreases and hence the uptake of the biomass also reduces [27]. Therefore, the biosorbents used for removal of $\mathrm{Pb}$ (II) the $\mathrm{pH}$ should be maintained at $\mathrm{pH} 5$ or lower, to avoid lead precipitation. Similar findings agree with that reported by using waste biomass of Corynebacterium glutamicum and also by using Groundnut hull at pH $5[28,29]$.

\subsection{Effect of contact time}

The effect of biosorption of $\mathrm{Pb}$ (II) on $A$. cookii was studied by taking $200 \mathrm{mg} / \mathrm{L}^{-1}$ of $\mathrm{Pb}$ (II) solution with $2 \mathrm{~g} / \mathrm{l}$ of $100 \mu \mathrm{m}$ particle size in a clean conical flask. The resulting mixture was subjected to various time intervals from 5-90 min. It was observed that the biosorption of $\mathrm{Pb}$ (II) up to $(98.52 \%)$ increases with increasing contact time up to $60 \mathrm{~min}$ and became constant. These results indicate that the sorption process can be considered very fast because of the largest amount of active adsorption sites within $20-30$ min. The maximum adsorption attained was at 60 min reaching almost $98.52 \%$ of the removal of $\mathrm{Pb}$ (II). The percentage removal of $\mathrm{Pb}$ (II) ions with contact time is shown in Fig 4.

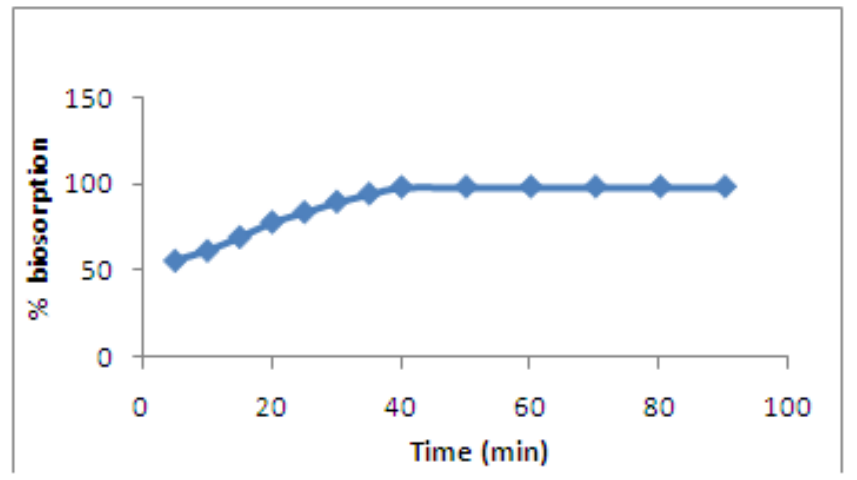

Figure. 4 Effect of contact time on adsorption of $\mathrm{Pb}$ (II) by A.cookii

The sour sop seed, bamboo dust and commercial activated carbon were used as a biosorbent for the removal of Lead [30, 31].

\subsection{Effect of Adsorbent dose}

In order to find out the effect of dosage for the removal of $\mathrm{Pb}$ (II) from aqueous solution were investigated by varying the dosage from 0.5 to $4.0 \mathrm{~g} / \mathrm{L}^{-1}$. The Fig- 5 depicts that the percentage removal increases with increasing in biosorbent dosage of $98.52 \%$. It is expected that on increasing biosorbent dose will 
have more surface area and adsorption sites. Afterwards, there was a negligible increase in the percentage removal beyond the dose of $2 \mathrm{~g} / \mathrm{l}$. This is due to the agglomeration of particles which causes the stable in adsorption rate. Based on this result, a dose of $2 \mathrm{~g} / 1$ was considered sufficient for the optimal removal of metal ions. Similar results were reported for the removal of $\mathrm{Pb}$ (II) by groundnut hull and by using Rice Husk and its ash [29, 32].

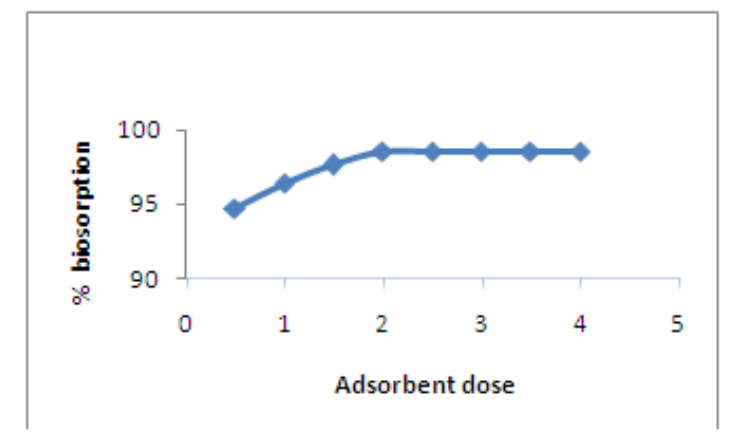

Figure.5 Effect of adsorbent dose on adsorption of $\mathrm{Pb}$ (II) by A.cookii

\subsection{Effect of Metal ion Concentration}

Initial concentration of $\mathrm{Pb}$ (II) was varied from $50-250 \mathrm{mg} / \mathrm{L}^{-1}$ and the quantity of biosorbent was kept constant at $2 \mathrm{~g} / \mathrm{l}, \mathrm{pH} 6$ maintained with contact time $60 \mathrm{~min}$. Fig- 6 shows that the percentage of biosorption decreases from $99.5 \%$ to $78.82 \%$ with increase in the metal ion concentration. It was observed that with the high concentration of metal ions there is a competition between metal ions to adsorb on the active site of adsorbent because less number of active site is available as compared to the metal ions. So there is a decrease in the adsorption efficiency with the increasing of metal ion concentration. Similar results were reported by using Nordmann fir cones to remove Lead (II) and Zinc (II) and Rice straws for removal of Pb (II) [33, 34].

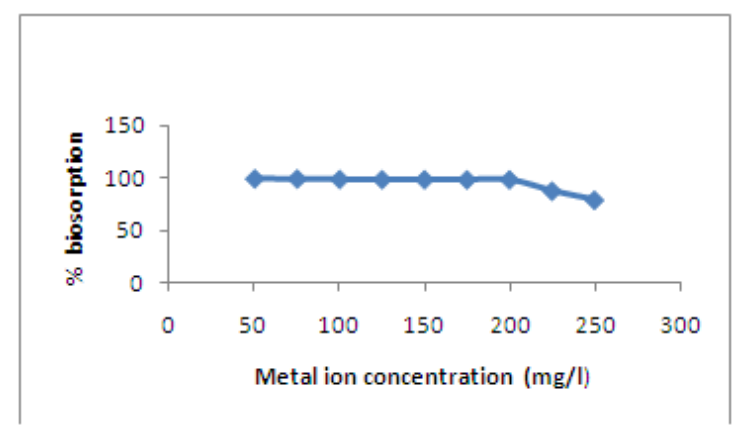

Figure.6 Effect of metal ion concentration of $\mathrm{Pb}$ (II) by A.cookii

\subsection{Effect of particle size}

In order to study the effect of particle size on the removal of $\mathrm{Pb}$ (II) ion from an aqueous solution, various sizes of $100 \mu \mathrm{m}$ to $400 \mu \mathrm{m}$ were introduced. Fig-7 shows that as the particle size increases from $100 \mu \mathrm{m}$ to $400 \mu \mathrm{m}$, the rate of adsorption decreases from $98.52 \%$ to $70.0 \%$. This is because the surface area per volume is higher for smaller particles with increase in the binding sites and contact surfaces, which shows that there is more rapid sorption and high mass transfer compared to the larger particles when they are used. The maximum uptake for the metal ion was obtained at $100 \mu \mathrm{m}$ of $98.52 \%$ and found to be the best among other particle sizes.

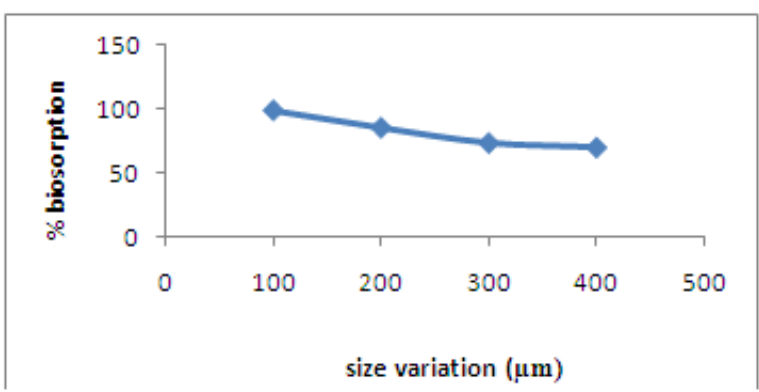

Figure.7 Effect of particle size of $\mathrm{Pb}$ (II) by A.cookii 


\subsection{Biosorption Kinetics / Kinetic studies}

The $\mathrm{Pb}$ (II) biosorption on A. cookii leaves was investigated using Pseudo- first order and Pseudosecond order kinetic models.

The simple Pseudo first- order equation was first suggested by Lagergren [35] and the model integrated in linearized form is expressed as

$\log \left(\mathrm{q}_{\mathrm{e}}-\mathrm{q}_{\mathrm{t}}\right)=\log \mathrm{q}_{\mathrm{e}}-\mathrm{k}_{1} \mathrm{t} / 2.303$

Where $\mathrm{k}_{1}$ is the adsorption rate constant $\left(\mathrm{min}^{-1}\right)$, $\mathrm{q}_{\mathrm{e}}$ metal biosorbed at equilibrium $\left(\mathrm{mg} \mathrm{g}^{-1}\right)$, $\mathrm{q}_{\mathrm{t}}$ metal biosorbed at any time $\mathrm{t}\left(\mathrm{mg} \mathrm{g}^{-1}\right)$. Fig. 8 shows the plot $t$ against $\log \left(\mathrm{q}_{\mathrm{e}}-\mathrm{q}_{\mathrm{t}}\right)$ for the metal biosorption with straight line which shows that the data fitted with poor correlation co-efficient indicating that pseudo first order equation did not apply for the removal of $\mathrm{Pb}$ (II) from A.cookii.

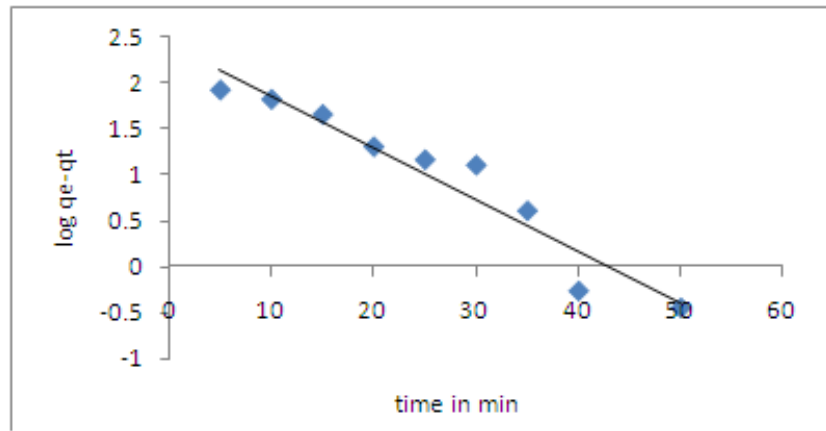

Figure.8 Pseudo first - order biosorption Kinetics for $\mathrm{Pb}$ (II) by A.cookii

Table -3 Pseudo- first order and Pseudo -second order kinetics for Pb (II) biosorption by A.cookii

\begin{tabular}{lccccccc}
\hline Metal & \multicolumn{3}{c}{ Pseudo first order } & \multicolumn{3}{c}{ Pseudo second order } \\
\hline $\mathrm{Pb}(\mathrm{II})$ & $\mathrm{q}_{\mathrm{e}}\left(\mathrm{mg} \mathrm{g}^{-1}\right)$ & $\mathrm{K}_{1}\left(\mathrm{~min}^{-1}\right)$ & $\mathrm{R}^{2}$ & $\mathrm{q}_{\mathrm{e}} \mathrm{mg} \mathrm{g}^{-1}$ & $\mathrm{~K}_{2}\left(\mathrm{~g} \mathrm{mg}^{-1} \mathrm{~min}\right)$ & $\mathrm{R}^{2}$ & $\mathrm{~h}$ \\
& & & & & & & \\
\hline & 1.247 & 0.004 & 0.976 & 1.820 & 0.130 & 0.996 & 0.430
\end{tabular}

The rate expression of Pseudo-second order reaction in linearized form which many scientists use has been utilized as follows:

$$
\mathrm{t} / \mathrm{q}_{\mathrm{t}}=1 / \mathrm{k}_{2} \mathrm{qe}^{2}+1 / \mathrm{q}_{\mathrm{e}} \mathrm{t}
$$

Where, $\mathrm{k}_{2}$ is equilibrium rate constant for second order model $\left(\mathrm{g} \mathrm{mg}^{-1} \mathrm{~min}^{-1}\right), \mathrm{q}_{\mathrm{e}}$ is the equilibrium capacity and $\mathrm{q}_{\mathrm{t}}$ is the biosorption capacity at any time $\mathrm{t}$. The plotting of time, $\mathrm{t}$ against $\mathrm{t} / \mathrm{qt}$ shows straight line as shown in Fig 9.

The biosorption rate, $\mathrm{h}(\mathrm{mg} / \mathrm{g} \mathrm{min})$ at $\mathrm{t}=0$ is shown as:

$$
\mathrm{h}=\mathrm{K}_{2} \mathrm{qe}^{2}
$$

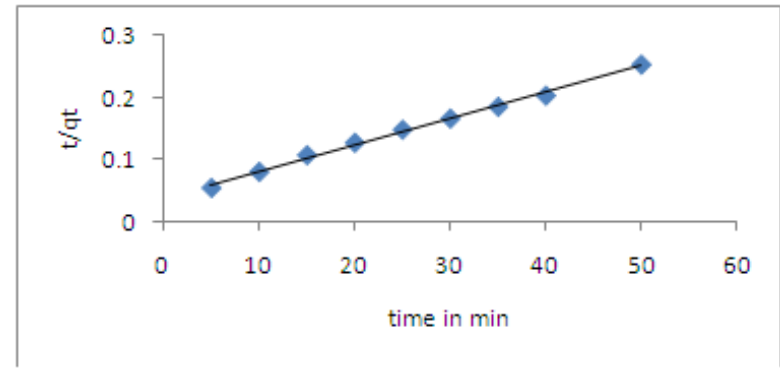

Figure.9 Pseudo second- order biosorption Kinetics for $\mathrm{Pb}$ (II) by A.cookii

In the present system, Pseudo-second order shows the applicability of correlation coefficient $\left(R^{2}\right) 0.996$ and the values of equilibrium rate constant $\mathrm{k}_{2} 0.130 \mathrm{gmg}^{-1} \min$ and equilibrium capacity $\mathrm{q}_{\mathrm{e}} 1.820 \mathrm{mg} \mathrm{g}^{-1}$ were shown from the slope and intercept of the lines. Table-3 and Fig- 8 shows that the poor description of data in Pseudo first-order equation. In the Pseudo second-order equation, the data fit well and a straight line was obtained, which suggests that the adsorption capacity depend only on this kinetic model. The rate limiting step in the adsorption mechanism involves chemisorptions which purely depend on physico-chemical interactions between adsorbent and solution in the metal removal [36]. 
Biosorption of Lead in Aqueous solution and Industrial Effluent by using leaves of Araucaria .....

\subsection{Biosorption equilibrium}

In the literatures several models has been used to describe the data of biosorption isotherms. In the present work, Langmuir [37] and Freundlich [38] models were used and Langmuir mathematical transformation of isotherm equation is shown as:

$\mathrm{q}=\mathrm{q}_{\max } \mathrm{bC} \mathrm{C}_{\mathrm{e}} / 1+\mathrm{bC} \mathrm{e}_{\mathrm{e}}$

Where $\mathrm{q}(\mathrm{mg} / \mathrm{g})$ is the amount of metal adsorbed per unit mass of adsorbent and $\mathrm{Ce}(\mathrm{mg} / \mathrm{L})$ is the equilibrium concentration of adsorbate in solution after adsorption. $\mathrm{q}_{\max }$ and $\mathrm{b}$ are Langmuir adsorption coefficient and Langmuir constant.

Figure 10 shows the graph plotted $\mathrm{C}_{\mathrm{e}} / \mathrm{q}_{\mathrm{e}}$ vs $\mathrm{C}_{\mathrm{e}}$ where intercept and slope can be calculated. The $\mathrm{q}_{\max }$ value is 37.03 ; $b$ is 0.0267 and correlation coefficient $\left(R^{2}\right)$ as 0.966 respectively as shown in Table 4 .

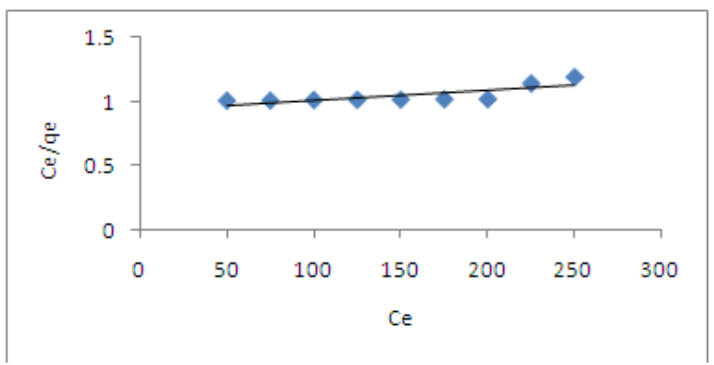

Figure.10 Langmuir adsorption isotherms of $\mathrm{Pb}$ (II) by A.cookii

Table -4 Langmuir and Freundlich isotherms for Pb (II) biosorption by A.cookii

\begin{tabular}{lcccccc}
\hline Metal & \multicolumn{3}{c}{ Langmuir } & \multicolumn{3}{c}{ Freundlich } \\
\hline $\mathbf{P b}$ (II) & $\mathbf{q}_{\max }$ & $\mathbf{b}$ & $\mathbf{R}^{\mathbf{2}}$ & $\mathbf{K}_{\mathbf{f}}$ & $\mathbf{1 / n}$ & $\mathbf{R}^{\mathbf{2}}$ \\
\cline { 2 - 7 } & 37.03 & 0.0267 & 0.966 & 29.51 & 1.054 & 0.991 \\
\hline
\end{tabular}

Freundlich isotherm equation is shown as:

$\mathrm{q}=\mathrm{K}_{\mathrm{f}}\left(\mathrm{C}_{\mathrm{e}}\right) 1 / \mathrm{n}$

(9)

Where $\mathrm{K}_{\mathrm{f}}$ is the Freundlich constant indicative of the relative adsorption capacity of the adsorbent $(\mathrm{mg} / \mathrm{g})$ and the constant $1 / \mathrm{n}$ indicates the tendency of the adsorbate to be adsorbed $[39,40]$.

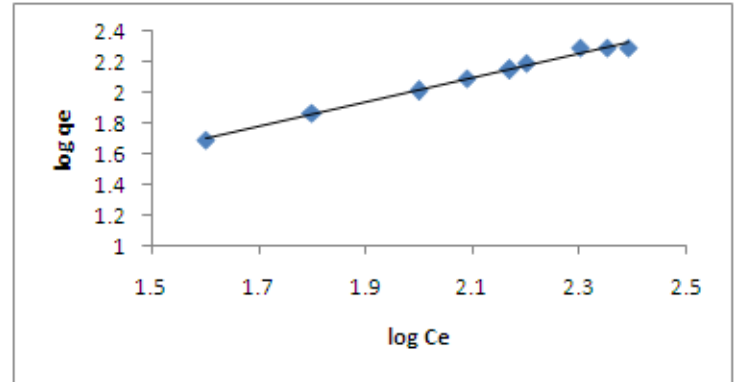

Figure.11 Freundlich adsorption isotherms of $\mathrm{Pb}$ (II) by A.cookii

\subsection{Central Composite Design Model}

In the present study Response Surface Method (RSM) is used to optimize different parameters which include $\mathrm{pH}$, biomass, metal ion concentration, contact time and size variation as shown in Table 1 . The data obtained were fitted to a second-order polynomial equation. Subsequent regression analyses, analyses of variance (ANOVA) and response surfaces were performed using the Design Expert Software (Version 8.0.7.1). The experimental data with multiple regression analysis was obtained from the following regression equation for the biosorption of Lead:

$\%$ Biosorption for lead $=75.26+4.20 * \mathrm{~A}+1.69 * \mathrm{~B}-4.71 * \mathrm{C}+19.09 * \mathrm{D}-14.21 * \mathrm{E}-11.84 * \mathrm{~A}^{2}-1.68 * \mathrm{~B}^{2}-13.82 * \mathrm{C}^{2}-$ $7.62 * \mathrm{D}^{2}+4.97 * \mathrm{E}^{2}+0.0781 * \mathrm{AB}+1 * \mathrm{AC}+0.188 * \mathrm{AD}-0.187 * \mathrm{AE}+0.143 * \mathrm{BC}+0.238 * \mathrm{BD}-0.238 * \mathrm{BE}$ $-0.625 * \mathrm{CD}+0.625 * \mathrm{CE}+1.17 * \mathrm{DE}$

Where $\mathrm{A}, \mathrm{B}, \mathrm{C}, \mathrm{D}$ and $\mathrm{E}$ are the code values for the independent variables, $\mathrm{AB}, \mathrm{AC}, \mathrm{AD}, \mathrm{AE}, \mathrm{BC}, \mathrm{BD}$, $\mathrm{BE}, \mathrm{CD}, \mathrm{CE}, \mathrm{A} 2, \mathrm{~B} 2, \mathrm{C} 2, \mathrm{D} 2$, and E2 are the significant model terms for the biosorption of Lead.

The statistical significance of the second -order polynomial equation is evaluated by the F-test of analysis of variance (ANOVA) as shown in Table 4. Probability> F value indicates the adequacy of any model. Model having prob $>$ F values less than 0.0001 means that the experimental data obtained can be experimentally 
Biosorption of Lead in Aqueous solution and Industrial Effluent by using leaves of Araucaria .....

explained with $99 \%$ accuracy by the model generated by RSM [41] whereas a low p-value $(<0.05)$ indicates that the model is considered to be statistically significant[42]. The F-value of 34.65 and $p$ - value of $<0.0001$ shows that the model is statistical significance. The relationship between the independent variables and response can be explained by the regression model. The model is best suited by determination of correlation $\mathrm{R}^{2} 91.6 \%(0.916)$ value which is close to $1[43]$.

In this model A, B, C, D and E represents the $\mathrm{pH}$, Biomass, Concentration, Contact time and Size variation respectively. Table 5 gives comparison between the actual values and predicted values obtained from the experimentation by establishing the validity of the model and also these two sets of values shows that they are in a close agreement with each other.

Table 5: ANOVA for Response Surface Method

\begin{tabular}{|c|c|c|c|c|c|}
\hline Source & $\begin{array}{c}\text { Degree of } \\
\text { freedom }\end{array}$ & Sum of squares & Mean square & F value & P value \\
\hline Model & 10 & 4813.195 & 481.3195 & 34.65524 & $<0.0001$ \\
\hline Residual & 32 & 444.4414 & 13.88879 & & \\
\hline Total & 42 & 5257.636 & & & \\
\hline $\mathrm{A}$ & 1 & 70.16426 & 70.16426 & 5.051861 & $0.0316^{*}$ \\
\hline $\mathrm{B}$ & 1 & 9.995664 & 9.995664 & 0.719693 & 0.4025 \\
\hline $\mathrm{D}$ & 1 & 110.4359 & 110.4359 & 7.951439 & $0.0082^{* *}$ \\
\hline $\mathrm{E}$ & 1 & 2952.928 & 2952.928 & 212.6122 & $<0.0001^{* *}$ \\
\hline $\mathrm{A}^{2}$ & 1 & 812.9224 & 812.9224 & 58.53081 & $<0.0001^{* *}$ \\
\hline $\mathrm{B}^{2}$ & 1 & 259.337 & 259.337 & 18.67239 & $0.0001^{* *}$ \\
\hline $\mathrm{C}^{2}$ & 1 & 5.572332 & 5.572332 & 0.401211 & 0.5310 \\
\hline $\mathrm{D}^{2}$ & 1 & 251.4326 & 251.4326 & 18.10327 & $0.0002^{* *}$ \\
\hline $\mathrm{E}^{2}$ & 1 & 657.0442 & 657.0442 & 47.30751 & $<0.0001^{* *}$ \\
\hline
\end{tabular}

Table- 6 The actual and predicted values

\begin{tabular}{|c|c|c|c|c|c|c|c|}
\hline Standard Order & $A$ & B & c & $\mathrm{D}$ & $E$ & Actusl value [\%] & Predicted value [\%] \\
\hline 1 & 5 & 2 & 200 & 60 & 200 & 85.3 & 84.13638 \\
\hline 2 & 5 & 2 & 175 & 60 & 100 & 98.57 & 99.7997 \\
\hline 3 & 5 & 2 & 200 & 50 & 100 & 98.45 & 95.62593 \\
\hline 4 & 5 & 0.5 & 200 & 60 & 100 & 94.7 & 94.93589 \\
\hline 5 & 5 & 2 & 225 & 60 & 100 & 87.57 & 92.53321 \\
\hline 6 & 5 & 2 & 200 & 60 & 100 & 98.52 & 98.03043 \\
\hline 7 & 5 & 3.5 & 200 & 50 & 100 & 98.52 & 98.32101 \\
\hline 8 & 5 & 2 & 200 & 60 & 100 & 98.52 & 98.03043 \\
\hline 9 & 5 & 2 & 50 & 60 & 100 & 99.5 & 94.72583 \\
\hline 10 & 5 & 2 & 200 & 30 & 100 & 89.9 & 84.76862 \\
\hline 11 & 5 & 2 & 75 & 60 & 100 & 99.33 & 99.59659 \\
\hline 12 & 5 & 2 & 200 & 60 & 100 & 98.52 & 98.03043 \\
\hline 13 & 5 & 2 & 200 & 35 & 100 & 94.47 & 88.23898 \\
\hline 14 & 10 & 2 & 200 & 60 & 100 & 94.92 & 92.18604 \\
\hline 15 & 5 & 2 & 200 & 20 & 100 & 78.25 & 76.31582 \\
\hline 16 & 8 & 2 & 200 & 60 & 100 & 96.19 & 98.96298 \\
\hline 17 & 5 & 1 & 200 & 60 & 100 & 96.4 & 96.24137 \\
\hline 18 & 2 & 2 & 200 & 60 & 100 & 79.07 & 83.78035 \\
\hline 19 & 5 & 2 & 200 & 60 & 300 & 73.5 & 74.66362 \\
\hline 20 & 5 & 3 & 200 & 60 & 100 & 98.52 & 98.65931 \\
\hline 21 & 5 & 2 & 200 & 60 & 100 & 98.52 & 98.03043 \\
\hline 22 & 4 & 2 & 200 & 60 & 100 & 97.17 & 94.76013 \\
\hline 23 & 3 & 2 & 200 & 60 & 100 & 94.22 & 90.0101 \\
\hline 24 & 5 & 2 & 150 & 60 & 100 & 98.66 & 99.8409 \\
\hline 25 & 5 & 2 & 250 & 60 & 100 & 78.82 & 85.30799 \\
\hline 26 & 5 & 2.5 & 200 & 60 & 100 & 98.52 & 98.51402 \\
\hline 27 & 5 & 4 & 200 & 60 & 100 & 98.52 & 93.14738 \\
\hline 28 & 5 & 2 & 200 & 5 & 100 & 56.25 & 59.85644 \\
\hline 29 & 5 & 2 & 200 & 25 & 100 & 83.92 & 80.79423 \\
\hline 30 & 5 & 2 & 200 & 80 & 100 & 98.52 & 98.72365 \\
\hline 31 & 7 & 2 & 200 & 60 & 100 & 97.72 & 100.1319 \\
\hline 32 & 5 & 2 & 200 & 70 & 100 & 98.52 & 98.41885 \\
\hline 33 & 5 & 2 & 200 & 60 & 100 & 98.52 & 98.03043 \\
\hline 34 & 5 & 2 & 200 & 90 & 100 & 98.25 & 99.82101 \\
\hline 35 & 5 & 2 & 125 & 60 & 100 & 98.72 & 99.1541 \\
\hline 36 & 5 & 2 & 200 & 15 & 100 & 69.73 & 71.33339 \\
\hline 37 & 6 & 2 & 200 & 60 & 100 & 98.25 & 91.20532 \\
\hline 38 & 9 & 2 & 200 & 60 & 100 & 95.75 & 96.31437 \\
\hline 39 & 5 & 2 & 200 & 5 & 100 & 70.00 & 69.61213 \\
\hline 40 & 5 & 2 & 200 & 10 & 100 & 61.88 & 65.84693 \\
\hline 41 & 5 & 1.5 & 200 & 60 & 100 & 97.64 & 97.27288 \\
\hline 42 & 5 & 3.5 & 200 & 60 & 100 & 98.52 & 96.79116 \\
\hline 43 & 5 & 2 & 100 & 60 & 100 & 98.9 & 99.7394 \\
\hline
\end{tabular}




\subsubsection{Response surface plots}

The 3D response surface plots are helpful in order to understand the effect of interaction of any two factors at fixed levels. The response plots are used to determine the interaction of variables at optimum level of each variable. Graphs have been plotted keeping center points constant and varying two factors at a time. Fig 12 - 14 shows the response curve plots with effect of solution concentration for the removal of Lead (II).

\subsubsection{Removal of $\mathrm{Pb}$ (II) with effect of $\mathrm{pH}$ and initial metal concentration by $A$. cookii}

The biosorption percentage of $\mathrm{Pb}$ (II) by leaves of $A$. cookii was studied by the selected range of $\mathrm{pH}$ and initial metal concentration. Fig 12. depicts that the maximum biosorption occurred at $\mathrm{pH} 6$ which is in the acidic range and the results coincide by using Borasus flabellifer Coir Powder and the metal ion concentration was at $175 \mathrm{mg} / \mathrm{L}$ [44].

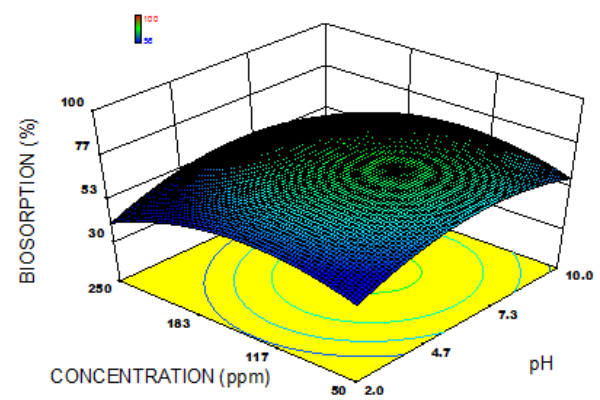

Figure. $12 \mathrm{RSM} 3 \mathrm{D}$ plot showing the effect of $\mathrm{pH}$ and Concentration for $\mathrm{Pb}$ removal by $\mathrm{A}$. cookii

\subsubsection{Removal of $\mathrm{Pb}$ (II) with effect initial metal concentration and Biomass by $A$. cookii}

The RSM 3D plot shows the combined effect of concentration and biomass for the removal of $\mathrm{Pb}$ (II). The results indicate that the maximum adsorption was at adsorbent dose of $2.25 \mathrm{~g} / 1$ at the initial metal ion concentration of $175 \mathrm{mg} / \mathrm{l}$ as shown in Fig 13 .

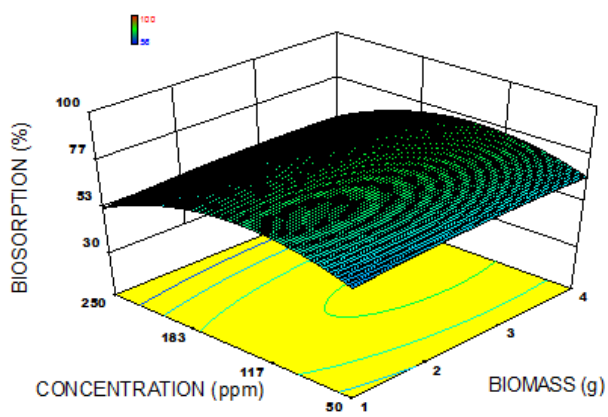

Figure. 13 RSM 3D plot showing the effect of concentration and biomass for $\mathrm{Pb}(\mathrm{II})$ removal A.cookii

\subsubsection{Removal of $\mathrm{Pb}$ (II) with effect initial metal concentration and Contact time by $A$. cookii}

The biosorption of $\mathrm{Pb}$ (II) shows the effect of concentration and contact time. Fig. 14 depicts the maximum removal of Lead in the optimized condition was at $32.5 \mathrm{~min}$ at the concentration of $175 \mathrm{mg} / \mathrm{l}$. There was no change after this point and the optimum time was considered as $32.5 \mathrm{~min}$ and the percentage removal was $91.6 \%$. 


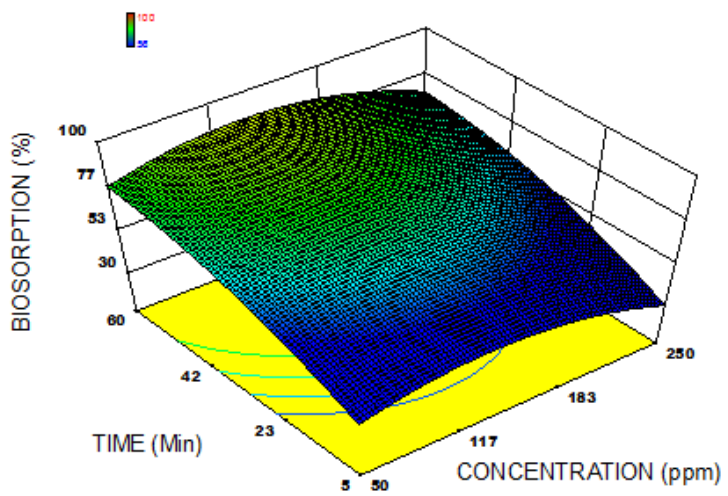

Figure. 14 RSM 3D plot showing the effect of Concentration and time for $\mathrm{Pb}$ removal $A$. cookii

The second order polynomial models with the set of metal ion concentration in the number of combinations were maintained at zero levels. Response surfaces were performed using the Design Expert Software (Version 8.0.7.1). The maximum adsorption for optimal set of Lead onto A. cookii is pH 6, metal ion concentration $175 \mathrm{mg} / \mathrm{L}$, particle size $250 \mu \mathrm{m}$, contact time $32.5 \mathrm{~min}$ and adsorbent dose $2.25 \mathrm{mg} \mathrm{L}^{-1}$. By using the optimum conditions for the removal of Lead was achieved at $91.6 \%$.

\subsection{Comparison of maximum biosorption capacity with other biosorbents}

Table 7 shows the comparison between other biosorbents including A.cookii for $\mathrm{Pb}$ (II) biosorption. The comparison of biosorption capacity shows that the leaves of A.cookii and Ficus religiosa (peepal) leaves has higher $\mathrm{q}_{\text {max }}$ value of the same range with those of various biomasses in literature. But it is difficult for the direct comparison due to various experimental conditions which is used in the studies.

Table- 7 Comparison of maximum biosorption capacity for $\mathrm{Pb}$ (II) with other plant biomass

\begin{tabular}{lcc}
\multicolumn{1}{c}{ Biosorbents } & \multicolumn{1}{c}{$\mathbf{q}_{\max }$} & \multicolumn{1}{c}{ Reference } \\
\hline $\begin{array}{l}\text { Ficus religiosa (peepal) leaves. } \\
\end{array}$ & $37.45 \mathrm{mg} / \mathrm{g}$ & Qaiser et al., 2007 [45] \\
& & \\
\hline $\begin{array}{l}\text { Biological Activated Dates } \\
\text { Stems }\end{array}$ & $27.03 \mathrm{mg} / \mathrm{g}$ & $\begin{array}{c}\text { Hynda yazid et al., } 2008 \\
\text { [46] }\end{array}$ \\
\hline Coir & $18.9 \mathrm{mg} / \mathrm{g}$ & K. Conrad etal., 2007 [47] \\
\hline Nordmann Fir & $29.3 \mathrm{mg} / \mathrm{g}$ & Yusuf Kaya et al., 2009 [33] \\
& & \\
\hline Groundnut hull & $31.54 \mathrm{mg} / \mathrm{g}$ & Qaiser et al., 2009 [48] \\
\hline Araucaria cookii & $37.03 \mathrm{mg} / \mathrm{g}$ & Present study \\
\hline
\end{tabular}

* $\mathrm{q}_{\max }$ is equilibrium and maximum adsorption capacity $(\mathrm{mg} / \mathrm{g})$

\section{Conclusion}

The leaves of A.cookii were evaluated as one of the possible biosorbent for the removal of Lead (II) from aqueous solution and also from Industrial effluent. The Lead (II) biosorption was influenced by $\mathrm{pH}$, contact time, initial metal ion concentration, adsorbent dose and size variation. The maximum biosorption was at $\mathrm{pH} 5.0$, contact time $60 \mathrm{~min}$ with the percentage removal of 98.52\%. Lead biosorption fit best in Pseudosecond order and equilibrium data by Langmuir and Freundlich isotherms with $\mathrm{R}^{2}$ value of 0.996 . The full factorial Central Composite Design (CCD) in Response Surface Methodology was used to determine the optimum conditions for the maximum percentage removal of Lead (II). The optimum conditions was at $\mathrm{pH} 6$, metal ion concentration $175 \mathrm{mg} / \mathrm{L}$, particle size $250 \mu \mathrm{m}$, contact time $32.5 \mathrm{~min}$ and adsorbent dose $2.25 \mathrm{mg} \mathrm{L}^{-}$ ${ }^{1}$ and correlation coefficient of 0.916 with the percentage removal of $91.6 \%$ Hence this method can be successfully employed to study the importance of individual, cumulative and interactive effects of different test variables of biosorption. 


\section{Acknowledgement}

The authors would like to acknowledge the University Grants Commission, New Delhi, for financial support under Rajiv Gandhi National Fellowship. The authors are thankful to Dr. Chandrasekhar, Mr. Yogesh for SEM analysis, IOE, University of Mysore, Mysore and Mr. Girish for FTIR analysis, Chemistry Department, University of Mysore, Mysore-05, Karnataka, India.

\section{References}

[1] B Volesky, Advances in biosorption of metals: selection of biomass types. FEMS Microbiology Reviews. 14, 1994, 291-302.

[2] B Volesky, and Z R Holan,. Biosorption of heavy metals Biotechnology Progress, 11, 2005, 235-250.

[3] M Kobya, E. Demirbas, and E. Senturk, Ince M, Adsorption of heavy metal ions from aqueous solutions by activated carbon prepared from apricot stone. Bioresour. Technol, 96 (13), 2005, 1518-1512.

[4] Phussadee Patnukao, Apipreeya Kongsuwan, and Prasert Pavasant, Batch studies of adsorption of copper and lead on activated carbon from. Eucalyptus camaldulensis Dehn. Bark, Journal of Environmental Sciences, 20, 2008, 1028-1034.

[5] Asma Saeed, Muhammed Iqbal, and Waheed Akhtar M, Removal and recovery of lead (II) from single and multimetal (Cd, Cu, Ni, Zn) solutions by crop milling waste (black gram husk), Journal of Hazardous Materials, 117, 2005, 65-73.

[6] World health organization, Guidelines for drinking water quality, (Geneva, Switzerland 1984).

[7] EPA (Environmental protection Agency), (Environmental pollution control Alternatives, EPA/625/5-90/025, EPA/625/4 89/023. Cincinnati, US, 1990).

[8] N.C Brady, and R.W Ray, The nature and properties of soil (Prentice-Hall, Inc: 743 1999).

[9] Schumann $\mathrm{K}$, The toxicology estimation of the heavy metal content $(\mathrm{Cd}, \mathrm{Hg}, \mathrm{Pb})$ in food for infants and small children. Z. Ernahrung swiss. 29, 1990, 54-73

[10] T. K Naiya, A. K Bhattacharya, S. Mandal, and S.K. Das, The sorption of Lead (II) ions on Rice Husk Ash. Journal of hazardous Materials, 163, 2009, 1254-1264.

[11] World Health Organization, Internal Programme on Chemical Safety (Environment health criteria, Geneva, 1995)

[12] E. M. B Sorensen, Lead in metal poisoning in Fish (Boca Raton: CRC Press Inc. 1991).

[13] Wang Yuen-Hua, Lin Su-Hsia., Juang, and Ruey-Shin, Removal of heavy metals from aqueous solutions using various low-cost adsorbents. Journal of Hazardous materials, 102, 1993, 291-302.

[14] S Karthikeyan, R. Balasubramanian, C. S. P Iyer, Evaluation of the marine algae Ulva fasciata and Sargassum sp. for the biosorption of $\mathrm{Cu}(\mathrm{II})$ from aqueous solutions Bioresource. Technol., 98, 2007, 452-455

[15] B Benguella, H Benaissa, Effects of competing cations on cadmium biosorption by chitin, Colloids Surf. A, 201, 2002143-150.

[16] B Volesky, Removal and recovery of heavy metals by biosorption. (In: Volesky B, ed. Biosorption of Heavy metals. Boca Raton: CRC press, 7-43 1990).

[17] G.E.P Box, N.R Draper, Emperical Model- Building and Response Surfaces, (John Wiley and sons, New York, 1987).

[18] M. A Bezerraa, R.E Santelli, E.P Oliveira, L.S Villar, and L.A.E Escale, Response surface methodology (RSM) as a tool for optimization in analytical chemistry, Talanta, 76, 2008, 965-977.

[19] APHA, (American Journal of Public Health, Vol. 88, Issue 9, 1998)

[20] M.J Anderson, and P.J Whitcomb, RSM simplified: optimizing processes using response surface methods for design of experiments (Productivity Press, New York 2005)

[21] D.C Montgomery, Design and analysis of experiments $\left(6^{\text {th }}\right.$ ed. John wiley \& Sons, Inc., USA 2005).

[22] C.A Toles, W.E Marshell, and M.M Johns, GAC from nutshells for the uptake of metal ions and organic compounds. Carbon, 35, 1997, 1414-1470

[23] R Elangovan, L. Pilip and Chandraraj K, Biosorption of Chromium species by Aquatic Weeds: Kinetics and Mechanism studies. Journal of Hazardous Materials, 152, 2008, 100-112

[24] N Ertugay, and Y. K Bahyan, Biosorption of Cr (VI) from aqueous solutions by biomass of Agaricus bisporus. Journal of Hazardous Materials, 154, 2008, 432-439,

[25] B.Y.O Bueno, M.L Torem, F Molina, and L.M.S de Mesquita, Biosorption of Lead (II) Chromium (III) and Copper (II) by R. Opacus: Equilibrium and Kinetic studies. Minerals Engineering, 21, 2008, 65-75.

[26] B Volesky, Sorption and biosorption. Montreal (St. Lambert, Quebec, Canada, BV Sorbex Inc., 316, p. ISBN 0-9732983-0-8, 2003)

[27] Schecher WD MINEQL+: A chemical Equillibrium Model for Personal Computers, Users Manual Version 2.22. Hallowell: Environmental Reserach Software, Inc. 1991).

[28] S. B Choi, Y.S Yun, Lead biosorption by waste biomass of Corynebacterium glutamicum generated from lysine fermentation process. Biotechnology Letters 26, 2004, 331-336.

[29] Suleman Qaiser, R. Anwar, Saleemi, Muhammad Umar, Biosorption of lead (II) and Chromium (VI) on groundnut hull: Equilibrium kinetics and thermodynamics study. Electronic Journal and Biotechnolgy, 12 (4), 2009.

[30] I. Oboh, E. Aluyor, and T Audu, Biosorption of Heavy Metal Ions from Aqueous Solutions Using a Biomaterial. Leonardo Journal of Sciences, 14, 2009, 58-65.

[31] N Kannan., and T Veemaraj, Removal of Lead (II) ions by Adsorption onto Bamboo Dust and Commercial Activated Carbons - a comparative study. E- Journal of Chemistry, 6(2), 2009, 247-56.

[32] A. G El- Said, Biosorption of Pb (II) Ions from Aqueous Solutions Onto Rice Husk and its Ash. Journal of American Science, 6 (10), 2010, 143-150.

[33] Yusuf Kaya., Ozkan Aksakal and Handan Ucun., Biosorption of Lead (II) and Zinc (II) from aqueous solutions by Nordmann Fir cones. Acta Chim. Slov, 56, 2009, 451-456.

[34] Hafiza Naila Khalid., Mukhtar-ul- Hassan., Nadia Jamil., Dania Ahmad., Hafza Bushra Fatima., Sara Khatoon., Biosorption of Aqueous Lead (II) on Rice Straws (oryza sativa) by Flash column process. Journal of scientific Research, 2010

[35] Lagergren, "About the theory of so called adsorption of soluble substances, (K.Sven Vetenskapsakad Handle, 24: 1 1898)

[36] Z Aksu, Equilibrium and kinetic modelling of cadmium (II) biosorption by C. Vulgaris in a batch system. Effect of temperature. Separation Purif. Technol., 21, 2001, 285-294.

[37] I. Langmuir, The adsorption of gases on plane surfaces of glass, mica and platinum. J. Am. Chem. Soc., 40 (8), $1918,1361-1403$.

[38] H. Freundlich, and H.Hatfield, Colloid and Capillary Chemistry. (Methuen and Co. Ltd., London 1926).

[39] P.L.Bishop, Pollution prevention: Fundamentals and practice, (Waveland Press Inc. 2004).

[40] J. Goel, K. Krishna, R. Chira, K. Vinod, Removal of lead (II) by adsorption using treated granular activated carbon and column studies. J. Hazard. Mater, B125, 2005, 211-220. 
[41] Suantak Kamsonlian and Bipin Shukla, Optimization of Process Parameters using Response Surface Methodology (RSM): Removal of Cr (II) from Aqueous Solution by wood Apple Shell Activated Carbon (WASAC). Research Journal of Chemical Science, 3(7), 2013, 31-37.

[42] R.H Myers and D.C Montgomery, Response Surface Methodology: Process and product optimization using designed experiments, (John Wiley and Sons, New York, , 798, 2002).

[43] U.K. Garg, M.P Kaur, V. K. Garg, D. Sud, Removal of Nickel (II) from aqueous solution by adsorption on agricultural waste biomass using a response surface methodological approach. Bioresource Technology, 99 (5), 2008, 1325-1331.

[44] D.Krishna, Siva Krishna and R. Padma sree, Response Surface Modelling and Optimization of Chromium (VI) Removal from aqueous solution using Borasus Flabellifer coir powder. International Journal of Applied Science and Engineering, 11 (2), 2013 , 213-226.

[45] Qaiser Suleman., Saleemi Anwar Rasheed and Umar Muhammad. Biosorption of Lead from aqueous solution by Ficus religiosa leaves: Batch and column study. Journal of Hazardous Materials, 166 (2-3), 2007, 998-1005.

[46] Hyanda Yazid and Rachida Maachi. Biosorption of Lead (II) from Aqueous Solutions by Biological Activated Dates Stems. Journal of Environmental Sciences and Technology, 1(4), 2008, 201-213.

[47] Conrad Katharine and Hansen Hans Christian Bruun. Sorption of Zinc and Lead on Coir. Bioresource Technology, 98 (1), 2007, 8997.

[48] Qaiser Suleman., Saleemi Anwar Rasheed and Umar Muhammad. Biosorption of Lead (II) and Chromium (VI) on ground nut hull: Equilibrium and thermodynamics study. Electronic Journal of Biotechnology, 12 (4), 2009. 